\title{
The Welfare States and Happiness Inequalities in Europe
}

\author{
Ümmügülsüm Aysan' 1 ๑
}

\begin{abstract}
Income distribution is a widely used measure of inequality, but in the assessment of welfare it is deemed to be insufficient. When measuring inequality in the distribution of welfare, subjective evaluations such as happiness and life satisfaction should also be taken into account. The purpose of this study was to analyze happiness inequalities in different welfare states in Europe. Overall happiness inequality, as well as happiness inequalities between different socioeconomic groups in these countries, were explored. Furthermore, this study analyzed how these inequalities changed over time. The European Quality of Life Survey (EQLS) data set was used for the analysis. Independent sample t-test and one way ANOVA were also used. All analyses were done using the IBM SPSS 22 program. It was found that social democratic welfare states which consistently rank at the top of happiness rankings had the lowest overall happiness inequalities. Happiness inequalities among different sociodemographic population groups were also low in these countries. On the contrary, post-socialist welfare states had the highest happiness inequalities. Compared to employed people the unemployed were significantly unhappy in corporatist countries. Postsocialist and southern European welfare states stood out as having high happiness inequalities between those with good and poor health and between the young and elderly.
\end{abstract}

\section{Keywords}

Happiness, inequality, welfare states, life satisfaction, social policy

1 Corresponding author: Ümmügülsüm Aysan (Asst. Prof. Dr.), University of Health Sciences, Hamidiye Faculty of Health Sciences, Department of Social Work, Istanbul, Turkey. E-mail: ummugulsum.aysan@sbu.edu.tr ORCID: 0000-0002-5489-763X

To cite this article: Aysan, U. (2021). The Welfare States and Happiness Inequalities in Europe. Journal of Social Policy Conferences, 81,71-99. https://doi.org/10.26650/jspc.2021.81.985095 


\section{Introduction}

Income distribution is a typically used inequality measure, but it falls short in the measurement of well-being due to the fact that every human being values material possessions differently. Furthermore, studies demonstrate that factors other than income, such as health and relationships, have a greater effect on happiness. Many people improve their material well-being while losing their relationships and their mental and physical health. Therefore, income is not enough to measure social well-being, and income distribution is an insufficient measure of true societal inequality. It is important to change the emphasis from income inequality to other well-being inequalities in order to discover ways of improving the well-being of both current and future generations.

An increasing number of academicians from different fields including economics, sociology, psychology, and social policy have started evaluating well-being via the individuals' level of self-reported happiness which is one of the most widely used indicators of subjective well-being. Happiness is possibly a more comprehensive indicator of inequalities in well-being than income-based measures given that it integrates everything a person cares about including health, income, family, social relationships, employment, and so on (Ovaska \& Takashima, 2010). The Stiglitz Commission emphasized the prominence of using measures of selfreported happiness in their report on the measurement of economic performance and social progress: "These measures, while not replacing conventional economic indicators, provide an opportunity to enrich policy discussions and to inform people's view of the conditions of the communities where they live. More importantly, the new measures now have the potential to move from research to standard statistical practice" (Stiglitz, Sen, \& Fitoussi, 2009).

Promisingly, there are signs that inequities in well-being are starting to be taken into consideration in both the political and policy arena. The Happiness Research Institute, a Danish think tank, produced a ranking of European countries based on happiness inequality at the beginning of 2015 (The Happiness Research Institute, 2015). In 2016 the World Happiness report took notice of the inequality of happiness within and among societies asserting that inequality of happiness is a more powerful indicator of the distribution of well-being than wealth and income (Helliwell, Layard, \& Sachs, World Happiness Report, 2016). In both of these reports, it was found that citizens of countries where there is less inequality of happiness are considerably happier. 
It is generally acknowledged that some societies enjoy higher levels of equity than others due to their welfare regimes (Esping-Andersen, 1990; Brady, 2009). Countries where there is very little inequality are, most notably, Nordic countries with "social democratic" welfare regimes. The "conservative" welfare states of continental Europe have a medium degree of inequality and AngloSaxon countries with "liberal" welfare regimes have the highest degrees of inequality (Thelen, 2014, Schröder, 2016). However, these studies generally assess inequality through income. Parallel to the growing interest in subjective well-being measurement both in academic and public arenas, researchers have recently started measuring inequalities in welfare states through alternative means such as happiness (Ott, 2005; Gainer, 2013).

Welfare states are claimed to reduce inequalities via several mechanisms. The size of social spending is one of them. On average, about 2/3rds of redistribution comes from the spending side (Mahler \& Jesuit, 2006). Estimates for the OECD member nations indicate that each additional 10 percent of social spending produces a one percent inequality reduction. Progressive taxation is another tool used to redistribute income. Decreasing child poverty by providing strong income support to needy families with children, providing a favorable infrastructure that encourages and allows mothers to work, and combatting unemployment are other tools used to decrease inequality. Last but not the least, tools to combat unemployment, including extensive day care services for little children, are important in reducing income inequalities in Scandinavian countries (Esping-Andersen \& Myles, 2012).

This study aims to analyze happiness inequalities in different welfare regimes in Europe. Happiness inequalities in European welfare regimes will be compared. Furthermore, happiness inequalities between different socioeconomic groups and, how these inequalities change over time, will be analyzed. This study first reviews the literature on happiness and happiness inequality and its relation to welfare regimes. Then, using the 2016 European Quality of Life Survey (EQLS) data set, happiness inequalities in welfare regimes will be analyzed.

\section{Literature Review}

\section{What is happiness?}

Since ancient times, philosophers and thinkers from diverse cultures and traditions have attempted to describe happiness. As it is a vague term that bears 
several meanings, it can be defined in several different ways; as a temporary emotion (synonymous with pleasure), as an experience of achievement and accomplishment (consequently particularly characterized by a cognitive assessment), as a longstanding process of identity improvement and meaningmaking through the actualization of virtuous potentials and pursuit of personally relevant dreams (Delle Fave, Brdar, Freire, Vella-Brodrick, \& Wissing, 2011).

Research on happiness across the social sciences focuses on two types of happiness; hedonic and eudaimonic. Hedonic happiness emphasizes the maximization of pleasure and the minimization of pain and happens when sensual pleasures and experiences offset pains. Its roots go back to Aristippus who taught that "the goal of life is to experience the maximum amount of pleasure and that happiness consists of the totality of one's hedonic moments". Positive affect, satisfaction with life, and the absence of negative affect are components of hedonic well-being. In contrast, according to Aristoteles the goal of life was to achieve "eudaimonia" or personal excellence (Ryff et al., 2021). Eudaimonic happiness focuses on the meaning of life and a feeling of self-realization that produces happiness as a by-product (Ryan \& Deci, 2001). It has been described as a kind of flourishing (Keyes \& Ed Haidt, 2003).

\section{How is it measured?}

There are numerous scales designed to gauge happiness. The most commonly used measures are single-item survey questions. For example, to a question about how things are these days, the respondent chooses a point on the scale between "1 (not too happy) and 10 (very happy)". If the researcher is interested in getting very brief information single-item measures can be sufficient. For example, The World Happiness Report, an annual publication of the United Nations Sustainable Development Solutions Network, contains a World Happiness Index that ranks countries by how happy their citizens perceive themselves to be using a single-item question. The most obvious advantage of single-item scales is their brevity, however they have several disadvantages. First, the scores are generally positively skewed. Second, there is the acquiescence problem; that is, the item is constantly scored in one direction. Lastly, a single question cannot include every aspect of a person's well-being, thus it depends on the respondent's formulation while giving a single response (Diener, 2009). 
Due to the deficiencies of single-item measures, many multi-item scales were created to measure happiness in more detail. Satisfaction with Life Scale is a 5-item scale designed to measure global cognitive judgments of one's life satisfaction. This scale assesses global life satisfaction and does not tap related constructs such as positive affect or loneliness (Diener, Emmons, Larsen, \& Griffin, 1985). The General Happiness Scale is a 4-item scale designed to measure subjective happiness. Individuals make an overall judgment of the extent to which they are happy or unhappy people (Lyubomirsky \& Lepper, 1999). The Positive and Negative Affect Schedule (PANAS) is a self-report questionnaire that is divided into mood scales. Participants evaluate their feelings and respond via a questionnaire with 20 items. Positive affect refers to positive emotions and expressions such as joy, optimism, or enthusiasm. Negative affect refers to negative emotions and expressions such as guilt, shame, or anger (Watson, Clark, \& Tellegen, 1988).

\section{What are the determinants of happiness?}

Researchers are trying to determine why some societies of people are happier or unhappier than others are. Finding out the determinants of happiness will enable us to understand how - and to what extent - the condition can be enhanced. Economists Bruno and Frey (2010) distinguish 5 types of determinants: “(a) Personality factors, such as self-esteem, personal control, optimism, extraversion, and neuroticism. (b) Socio-demographic factors, such as age, gender, marital status, and education. (c) Economic factors, such as individual and aggregate income, unemployment, and inflation. (d) Contextual and situational factors, such as particular employment and working conditions, the stress involved at the workplace, interpersonal relations with work colleagues, relatives, friends, marriage partners as well as living conditions and health. (e) Institutional factors, such as the extent of political decentralization and citizens' direct political participation rights."

Psychologists have extensively studied the personality and socio-demographic factors that affect happiness. In recent years economists and political scientists have started to study the macro factors that affect happiness at a societal level given that studies reveal there are obvious differences in happiness levels of different societies. According to the World Happiness Report 2018, which evaluates 158 nations based on their happiness levels, average life evaluations 
in the top 10 countries are more than twice as high as those in the worst 10, at 7.4 against 3.4. According to this report, 3 points of this 4-point difference can be explained by six factors including differences in healthy life expectancy, GDP per capita gap, social support, freedom, corruption perceptions, and generosity. However, income is the single largest contributor; the GDP per capita of the top ten countries is 25 times larger than the bottom ten countries' (Helliwell, Layard, \& Sachs, 2018).

\section{Happiness inequality}

Happiness inequalities can be measured between population groups, such as the young and the elderly, or people with a higher or lower level of education. Happiness inequality in the population can be measured without taking other factors like gender or income into account. For example, it is possible to compare the happiness scores of the top $10 \%$ and the lowest $10 \%$ of the happiness distribution (Quick, 2015).

If we accept happiness as a meaningful measure of individual and societal well-being, then the dispersion of its distribution gives an inclusive measure of inequality that incorporates the many varieties of inequality in specific realms. For instance, the relationship between the level of happiness and inequality of happiness may offer a valuable measure of the degree to which happiness differences are related to differences in inequality. Goff et. al (2016) found that differences in the variance of happiness in high-income countries explain as much of the difference in mean happiness as that in GDP per capita.

It is claimed that happiness assessed by life valuations offers a more inclusive indicator of human welfare than that provided by other measures such as health, education, income, poverty, and government quality. One step forward is the measurement of inequalities in happiness. As stated by the supporters of this argument, inequality of happiness offers a better measure of the distribution of welfare than is offered by income inequality (Helliwell, Layard, \& Sachs, 2016). According to the World Happiness Report, there is a wide variation between countries and regions in their inequality of happiness, and the degree of these inequalities has changed recently. There was a significant rise in happiness inequality in more than $50 \%$ of countries (Helliwell, Layard, \& Sachs, 2016). 
Decreasing happiness inequalities is important for the sake of social harmony and security. The discontent theories claim that people are more likely to rise against the authorities if the gap between the happiness of the most and least well off is large (Tullock, 1971; Gurr, 1994; Clark, Flèche, \& Senik, 2012). Hence, any effort to decrease inequalities will strengthen both societal harmony and the public order.

\section{Relationship between inequality of happiness and level of happiness}

The priority of utilitarians is achieving the highest average happiness according to principle of "the greatest happiness for the greatest number", and thus they agree to have some inequality in return. Egalitarians emphasize that people have the same rights to happiness. Thus, trade-offs between happiness level and equality and inequality in happiness are unacceptable. Studies indicate that the argument between the two has little practical importance because most of the studies that examine the relationship between average well-being and its dispersion have reported a strong negative correlation between the two (Ott, 2005; Quick, 2015; Goff, Helliwell, \& Mayraz, 2016). Countries with less happiness inequality usually have higher average happiness. For example, Ott (2005) found a correlation of $r=-0.65$ between happiness and happiness inequality. However, we cannot conclude that working to increase average happiness will always increase happiness inequalities. High average happiness and equitable happiness do not always go hand in hand (Quick, 2015). It should be noted that countries with very low average happiness scores such as Afghanistan and Rwanda also have little happiness inequality scores. Therefore, both objectives require simultaneous attention.

\section{Determinants of happiness inequality}

Although the literature on the determinants of happiness is burgeoning, the research on happiness inequality is very limited. Initial findings suggest that income, individual income inequality, quality and accessibility of public services, unemployment, and labor market conditions are some of the factors associated with happiness inequality.

Higher national income appears to be related to lower happiness inequality, at least in rich countries (Ott, 2005). It is generally acknowledged that income inequality and happiness inequality are related. However, research on this 
relation gives contradictory results. Stevenson and Wolfers (2008) found a decline in happiness inequality from the 1970s to the 2000s in the US, while income inequality has significantly increased. Thus, they state that income inequality and happiness inequality are not linked. Oishi et al. (2011), on the other hand, revealed low-income Americans were happier on average in years with less national income inequality than in years with higher national income inequality. Findings on other determinants are also embryonic; however, they are worth mentioning. Ovaska \& Takashima, (2010) found that better access to health care and political freedom are positively related to happiness inequality. An increase in the unemployment rate negatively affects happiness dispersion within societies, while enhanced education reduces inequality (Becchetti, Massari, \& Naticcioni, 2013; Aysan \& Aysan, 2017).

\section{Happiness in Welfare states}

The supporters of the welfare state argue that welfare improves peoples' well-being and decreases inequality through redistributing income, providing extended public services and protecting citizens from unemployment. Therefore, they advocate public policies that promote more equality and welfare such as better public health care, education, and pension systems (Bok, 2010; Aysan, 2020). Welfare's contribution to well-being is explained through "livability" in which institutional arrangements are compatible with human needs and capacities. The livability theory suggests that happiness depends on the satisfaction of needs, which in turn depends on both external living conditions and inner capacities to meet those needs. -If human needs are satisfied, happiness follows. Happiness will increase when the fit between social institutions and human needs improves (Veenhoven, 2014).

Others argue that the welfare state does not increase well-being. They argue that it hinders economic growth and creates a culture of dependency, making people more dependent, lazy, and less caring (Fraser \& Gordon, 1994). They also claim that welfare services are provided at the expense of increasing public debt (Lemieux, 2013). Furthermore, vote-seeking politicians can use it as a toy, not reflecting whether their policies are economically reasonable and efficient. They tend to overspend in order to increase their chances of re-election (Okulicz-Kozaryn, 2015). It is claimed that a welfare state system can lead to clumsy governmental intrusions into private life, thus causing issues with 
personal integrity, stigmatizing the poor, and pushing civil society and voluntarism out (Rothstein, 1998).

Empirical studies on the effect of the welfare state on happiness have contradictory results. Veenhoven (2000) finds no relationship between the size of a country's welfare state and its inhabitants' happiness in a cross-country survey of 40 countries conducted between 1980 and 1990. Furthermore, in another cross-country study of 74 countries, Bjornskov et al. (2007) find that higher government spending leads to lower life satisfaction. On the other hand, Di Tella et al. (2003) measure the welfare effect through the income replacement rate of unemployment benefits and find the effect of welfare on happiness is positive. Similarly, by using local public health care data, Katakorpi and Laamanen (2010) demonstrate that comparatively high public healthcare spending positively affects individuals' happiness.

Comparing the 18 most developed OECD countries, and measuring welfare via decommodification (the ability of the state to free its citizens from the externalities of the markets), social wage (unemployment benefit) and left-party dominance, Pacek and Radcliff (2008) conclude that happiness increases as the generosity of the welfare state increases. Supporting this argument, Nordic countries are generally at the top of the happiness lists created using international surveys. For instance, in the World Happiness Report 2018, Nordic countries topped the list of the happiest countries in the world outpacing some of the world's largest economies. Finland is the happiest country in the world followed by Norway, Denmark, Iceland, and Switzerland. These countries ranked ahead of developed countries such as Germany $\left(15^{\text {th }}\right)$, the US $\left(18^{\text {th }}\right)$, the U.K $\left(19^{\text {th }}\right)$, and France (23 $\left.{ }^{\text {rd }}\right)$ (World Happiness Report, 2018).

To sum up, the literature on the impact of the welfare state on happiness reveals a mixed picture. This is largely determined by the type of independent variables used to calculate the size of the welfare state, such as welfare spending as a percentage of GDP, decommodification level, the social wage, the degree of economic regulations, as well as the statistical methodologies employed. (Gainer, 2013).

Current literature on the impact of the welfare state on levels of happiness inequality remains mixed. Veenhoven (2000) states welfare spending, assessed via social security expenditures, is not related to the dispersion of happiness. 
Contrarily, Gainer (2013) using decommodification, the social wage, and leftwing government as indicators of the size of the welfare state, demonstrate that the latter has a considerable impact on happiness inequality. As the extent of the welfare state shrinks, the degree of inequality rises.

Ono and Lee (2013) argue happiness is redistributed amid policy-targeted demographic groups in social democratic welfare states. This redistribution process leads to an alternative kind of inequality wherein winners and losers are determined by their income, marital and employment status, and the presence of children. For example, family benefits that are designed to keep families safe from social risks lead to greater happiness for families at the expense of singles.

The purpose of this study is to analyze the happiness inequalities in different welfare states in Europe. The research questions are: "Are happiness inequalities between different welfare state regimes in Europe significantly different?" "Does inequality change over time?" "How do disparities in happiness between different sociodemographic groups look in different welfare states?" To address these questions happiness inequalities in European welfare regimes will be compared. Furthermore, the happiness level of different sociodemographic groups in these regimes will be explored. Also, how these inequalities change over time will be analyzed.

\section{Method and Data}

In this study, The European Foundation's European Quality of Life Survey (EQLS) datasets containing many questions about both cognitive and affective aspects of subjective well-being were used. The first EQLS (2003) was conducted in 28 countries, 27 of which are presently EU members while the remaining one, Turkey, is a candidate. In 2016 this number increased to 36 countries to include other candidate countries. EQLS has been repeated four times including wave 1 in 2003, wave 2 in 2008, wave 3 in 2012, and wave 4 in 2016.

In cross-country research, country clusters serve numerous functions such as building theory, clarification of the findings, and assistance to policymaking and assessment (Ahlquist \& Breunig, 2011). Esping-Andersen (1990) developed one of the most frequently used country groupings. He proposed new factors for measuring the level of social welfare, including the de-commodification 
index, social stratification, and the public-private nexus. Based on these variables he categorized the welfare states into three groups: liberal or AngloSaxon, social democratic or Nordic, and continental (conservative) regimes. Subsequent researchers have attempted to revise this classification opposing the distinction of a southern group of countries or trying to integrate the Eastern and Central European countries (Ferrera, 1996; Bob, 2000; Aysan, 2018). In this research, countries were grouped according to the Quality of life in Europe: Subjective Well-being Report (Eurofound, 2013). Turkey, which was not included in the report, was analyzed in the southern European group, and all Eastern and Central European countries were clustered into one group, namely, the post-socialist welfare states. Table 1 shows countries and country groups.

Table 1

Country Groups

\begin{tabular}{|c|c|c|c|c|c|c|c|}
\hline $\begin{array}{l}\text { Welfare } \\
\text { Regime }\end{array}$ & Country & $\mathbf{N}$ & $\begin{array}{c}\text { Mean } \\
\text { Happiness }\end{array}$ & $\begin{array}{l}\text { Welfare } \\
\text { Regime }\end{array}$ & Country & $\mathbf{N}$ & $\begin{array}{c}\text { Mean } \\
\text { Happiness }\end{array}$ \\
\hline \multirow{6}{*}{ 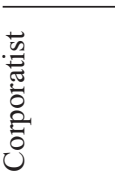 } & Austria & 4,232 & 7.71 & \multirow{7}{*}{ 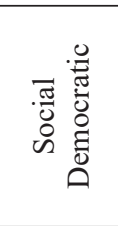 } & Denmark & 4,022 & 8.22 \\
\hline & Belgium & 4,021 & 7.63 & & Finland & 4,047 & 8.19 \\
\hline & Germany & 7,695 & 7.45 & & Netherlands & 3,994 & 7.78 \\
\hline & France & 6,017 & 7.44 & & Sweden & 4,058 & 8.00 \\
\hline & Luxembourg & 3,621 & 7.97 & & Norway & 992 & 8.01 \\
\hline & Total & 25,586 & 7.59 & & Iceland & 996 & 8.35 \\
\hline \multirow{12}{*}{ 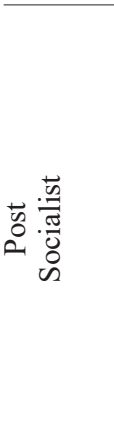 } & Bulgaria & 3,928 & 5.92 & & Total & 18,109 & 8.07 \\
\hline & Czech & 4,228 & 7.12 & \multirow{7}{*}{ 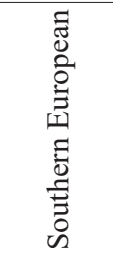 } & Cyprus & 3,594 & 7.38 \\
\hline & Estonia & 3,591 & 6.95 & & Greece & 4,089 & 6.75 \\
\hline & Croatia & 2,984 & 6.93 & & Spain & 4,500 & 7.60 \\
\hline & Hungary & 4,039 & 6.87 & & Italy & 6,715 & 7.01 \\
\hline & Lithuania & 4,113 & 6.72 & & Portugal & 4,052 & 6.98 \\
\hline & Latvia & 3,931 & 6.57 & & Turkey & 7,021 & 6.54 \\
\hline & Poland & 5,714 & 7.22 & & Total & 29,971 & 6.99 \\
\hline & Romania & 4,545 & 6.83 & \multirow{4}{*}{ 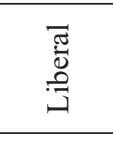 } & Ireland & 3,974 & 7.89 \\
\hline & Slovenia & 3,625 & 7.29 & & $\begin{array}{l}\text { United } \\
\text { Kinodom }\end{array}$ & 6,033 & 7.73 \\
\hline & Slovakia & 4,194 & 6.85 & & Total & 10,007 & 7.79 \\
\hline & Total & 44,892 & 6.85 & & & & \\
\hline
\end{tabular}

Source: European Quality of Life Survey, 2003-2007-2011- 2016

In EQLS, happiness was measured through a single question. Respondents were asked, "Taking all things together on a scale of 1 to 10, how happy would you say you are?" The happiness inequality variable was derived from the happiness variable. Inequality in welfare state regimes was defined as the standard deviation of reported happiness levels (Ott, 2005; Gainer, 2013). A low standard deviation means the data points are close to the set's mean, showing little inequality, whereas a high standard deviation means the data points are spread out over a wider range of values, indicating high inequality (The Happiness Research Institute, 2015). 
When there were only two groups, independent sample t-tests were used to determine whether there was any statistically significant difference between the groups. The one-way analysis of variance (ANOVA) was used to determine whether there were any statistically significant differences between the means when there were more than two independent groups. One-way ANOVA is an omnibus test statistic that tells that at least two groups are different. Since there were five welfare groups in the study, in order to determine which of these groups differ from each other post hoc tests were used. All analyses were done with IBM SPSS.

\section{Findings}

Graph 1. Happiness inequality in welfare state regimes

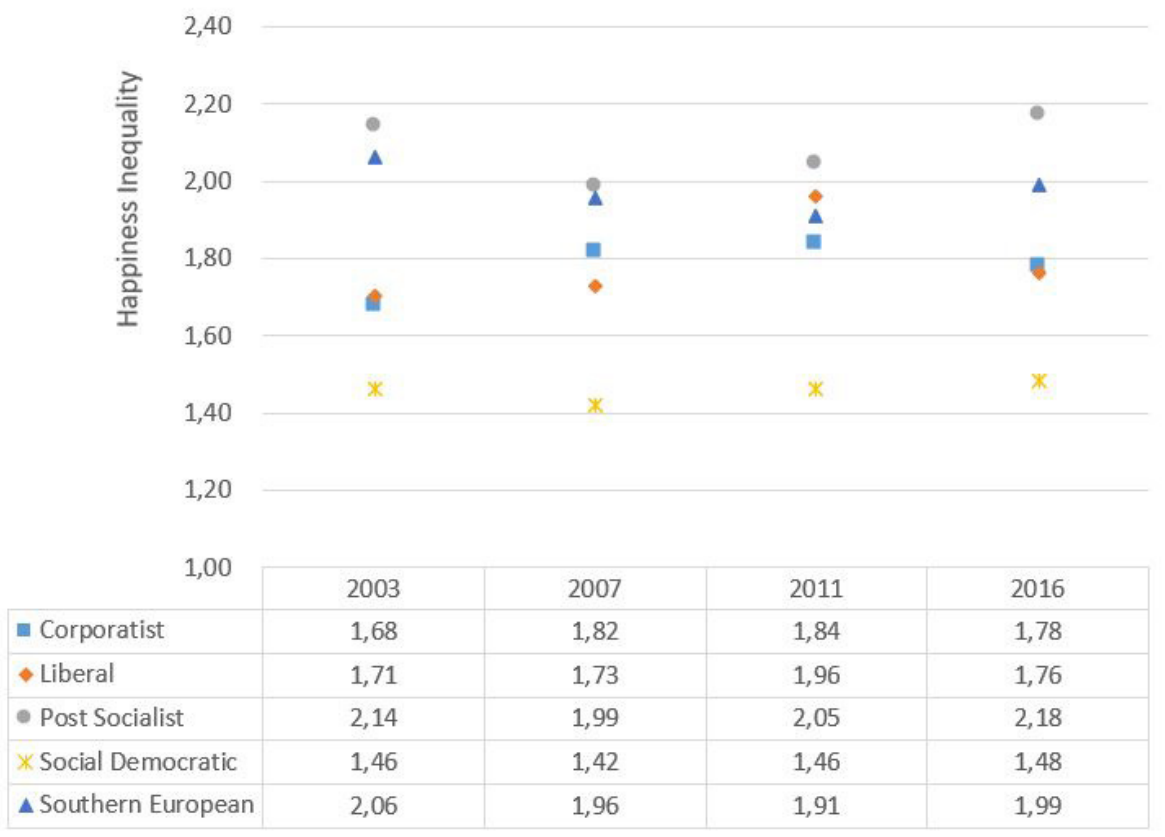

Source: European Quality of Life Survey, 2003-2007-2011- 2016

Graph 1 shows the evolution of European welfare states' inequality of happiness, as measured by the standard deviation of the distribution of the self-reported happiness on the 0 to 10 scale, from 2003 to 2016. A one-way ANOVA was performed to compare the effect of the welfare state on happiness 
inequality. There was a statistically significant difference in happiness inequality between at least two groups $(F(4,108)=[34.240], p=[0.00])$. Post hoc analyses using the Scheffé post hoc criterion for significance showed that the mean value of happiness inequality was significantly lower in social democratic welfare states than all other welfare states. Post-socialist and southern European welfare states stood out as having the highest happiness inequalities. There was no statistically significant difference in mean happiness inequality between postsocialist and southern European welfare states $(\mathrm{p}=0.99)$. Corporatist and liberal welfare states had moderate well-being inequalities. There was no statistically significant difference in mean happiness between corporatist and liberal welfare states $(\mathrm{p}=0.16)$.

The numbers showed a small increase in the level of happiness inequality in all welfare states from 2003 to 2016 except southern European welfare states. In the southern European group, inequality dropped from 1.97 in 2003 to 1.86 in 2012 and increased to 1.92 in 2016. In liberal countries, inequality rose from 1.71 in 2003 to 1.96 in 2012, however, it dropped to 1.76 in 2016. Although it was lower than its level in 2012, the inequality level in liberal welfare states was higher than its 2003 level. In corporatist welfare states, inequality rose from 1.68 in 2003 to 1.84 in 2012, then it dropped to 1.78 in 2016. In social democratic welfare states, inequality was the lowest and its level remained relatively stable throughout the years. It was 1.46 in 2003 and rose to 1.48 in 2016. In post-socialist countries inequality was 2.14 in 2003 and decreased to 1.99 in 2007. However, it started increasing again and reached 2.18 in 2016. One-way ANOVA was used to analyze whether the changes between years were significant for each welfare state group. Post hoc analysis revealed that the changes were not statistically significant except for the increase in postsocialist welfare states from 2007 to 2016 ( $p=.02)$. 
Graph 2. Happiness of the highest and lowest income quartiles

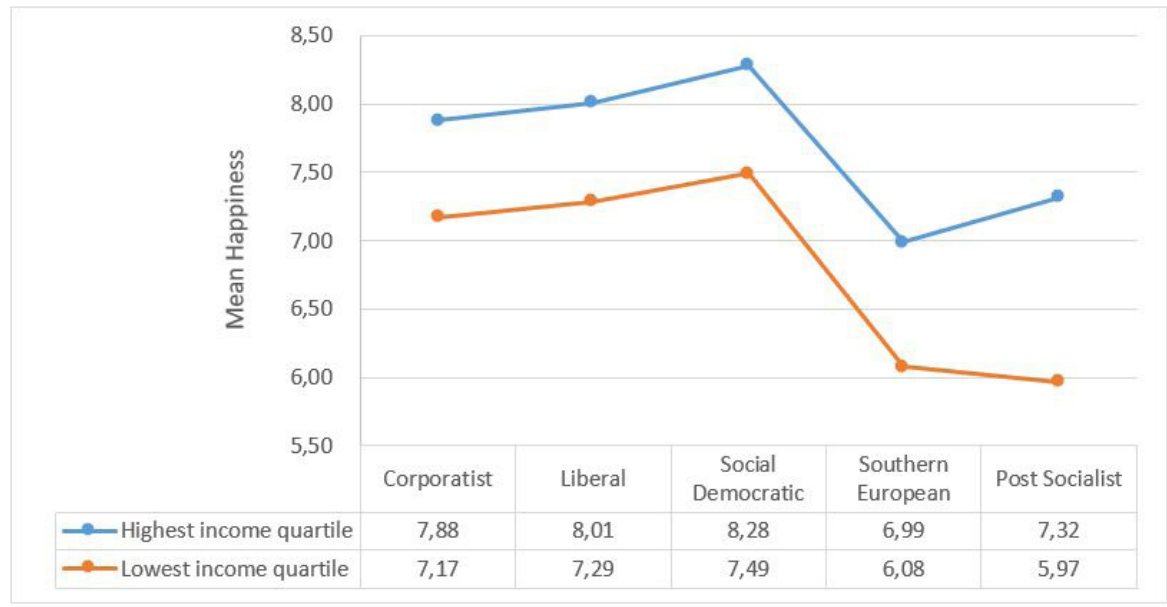

Source: European Quality of Life Survey, 2016

Graph 2 shows the mean happiness level of the highest and lowest income quartiles in European welfare states. Independent sample t-tests were conducted to analyze whether the highest and lowest income quartiles had significantly different happiness levels. Analysis revealed that the happiness mean of the highest income quartile was significantly higher than that of the lowest income quartiles for every welfare group. However the mean happiness difference was higher in southern European $(\mathrm{t}(3249)=-12.999, \mathrm{p}<.00)$ and post-socialist $(\mathrm{t}(4114)=-20.468, \mathrm{p}<.00)$ welfare states than in corporatist $(\mathrm{t}(2354)=-9.864$ $2.6, \mathrm{p}<.00)$, liberal $(\mathrm{t}(801)=-6.366, \mathrm{p}<.00)$ and social democratic $(\mathrm{t}(1978)$ $=-11.246, \mathrm{p}<.00)$ welfare states respectively. 
Graph 3. Happiness of unemployed vs. employed

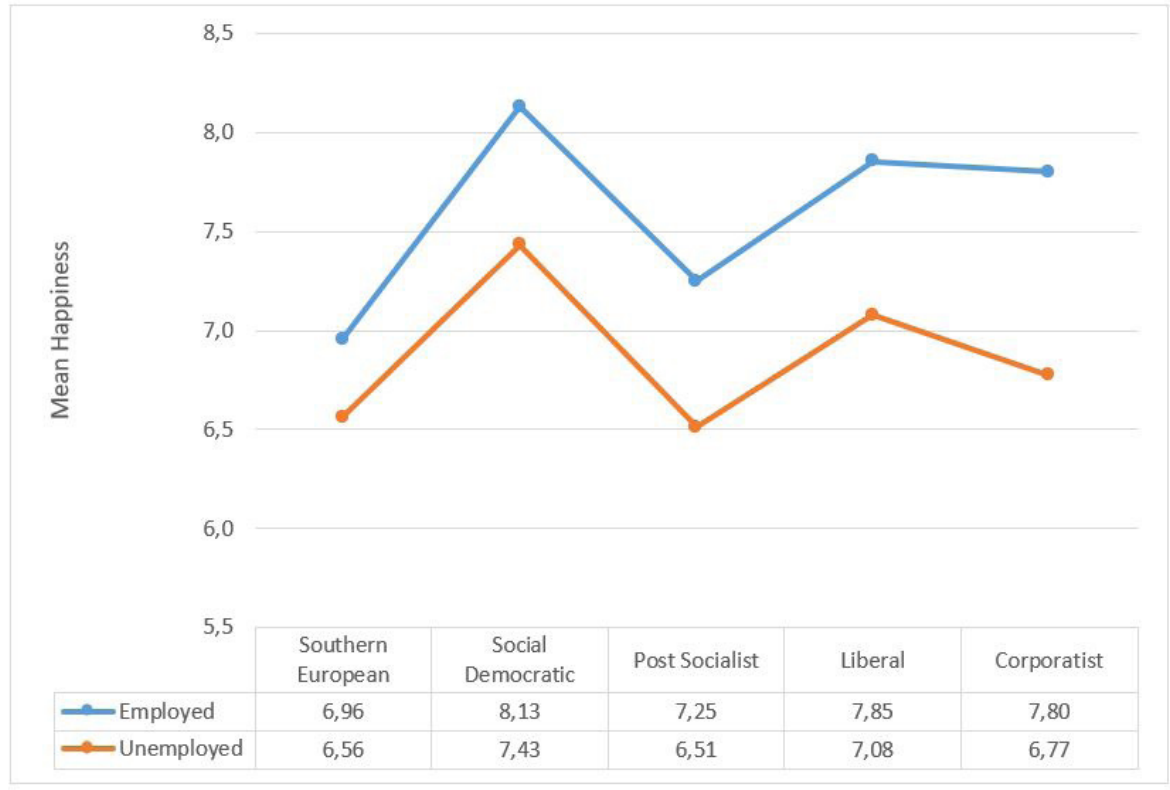

Source: European Quality of Life Survey, 2016

Graph 3 shows the mean happiness level of employed and unemployed individuals in European welfare state regimes. Independent sample t-tests revealed that the happiness level of the employed was significantly higher than that of the unemployed in every welfare state regime. However the difference was lowest in southern European countries (happiness mean difference $=0.39$ ) $(t(8172)=-11.925, p<.00)$. Inequality in social democratic countries (happiness mean difference $=0.69)(t(3971)=-6.29, p<.00)$, post-socialist countries (happiness mean difference $=0.73)(t(10772)=-23.47, p<.00)$ and liberal countries (happiness mean difference $=0.77)(t(2287)=-3.65, p<.00)$ was also significant. However, corporatist countries (happiness mean difference=1.02) $(t(4882)=-11.67, p<.00)$ stood out with the highest inequality between employed and unemployed people. 
Graph 4. Health status and happiness

\begin{tabular}{|c|c|c|c|c|c|c|}
\hline \multirow{12}{*}{ 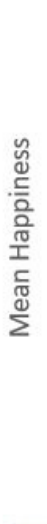 } & 9,00 & & & & & \\
\hline & 8,50 & \multirow{2}{*}{\multicolumn{2}{|c|}{ - }} & \multirow{2}{*}{\multicolumn{2}{|c|}{ - }} & \multirow{3}{*}{$\bullet$} \\
\hline & 8,00 & & & & & \\
\hline & 7,50 & 밈 & $\bullet$ & $\bullet$ & \multirow{2}{*}{$\bullet$} & \\
\hline & 7,00 & & \multirow{2}{*}{$=$} & 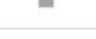 & & $\bullet$ \\
\hline & 6,50 & * & & & $\bullet$ & \multirow{2}{*}{ 물 } \\
\hline & 6,00 & & * & * & 볼 & \\
\hline & 5.50 & \multicolumn{2}{|l|}{+} & & & \multirow[b]{2}{*}{ * } \\
\hline & 500 & & + & + & * & \\
\hline & \multirow{2}{*}{4,50} & & & & \multirow[b]{2}{*}{+} & \multirow[b]{2}{*}{+} \\
\hline & & & & & & \\
\hline & $-1,00$ & $\begin{array}{c}\text { Social } \\
\text { Democratic }\end{array}$ & Corporatist & Liberal & $\begin{array}{l}\text { Southern } \\
\text { European }\end{array}$ & Post Socialist \\
\hline \multicolumn{2}{|c|}{ - Very good } & 8,52 & 8,26 & 8,27 & 7,38 & 7,94 \\
\hline \multicolumn{2}{|c|}{$\bullet$ Good } & 8,08 & 7,71 & 7,71 & 6,77 & 7,25 \\
\hline \multicolumn{2}{|c|}{ Fair } & 7,69 & 7,01 & 7,30 & 6,21 & 6,45 \\
\hline \multicolumn{2}{|c|}{ * Bad } & 6,81 & 6,10 & 6,03 & 5,38 & 5,39 \\
\hline \multicolumn{2}{|c|}{ + Very bad } & 5,88 & 5,14 & 5,12 & 4,32 & 4,28 \\
\hline
\end{tabular}

Source: European Quality of Life Survey, 2016

Graph 4 shows the mean happiness levels of individuals with diverse health conditions in welfare states. One-way ANOVA showed that the effect of health on happiness was significant for all welfare states. Although inequalities varied among different welfare states, people with better health conditions reported higher levels of happiness everywhere. The happiness mean difference between those with very good and very bad health was the lowest in social democratic countries $(F(4,4114)=129.787, p<.00)$ whereas it was the highest in postsocialist countries $F(4,11062)=491.426, p<.00)$. 
Graph 5. Marital Status and happiness

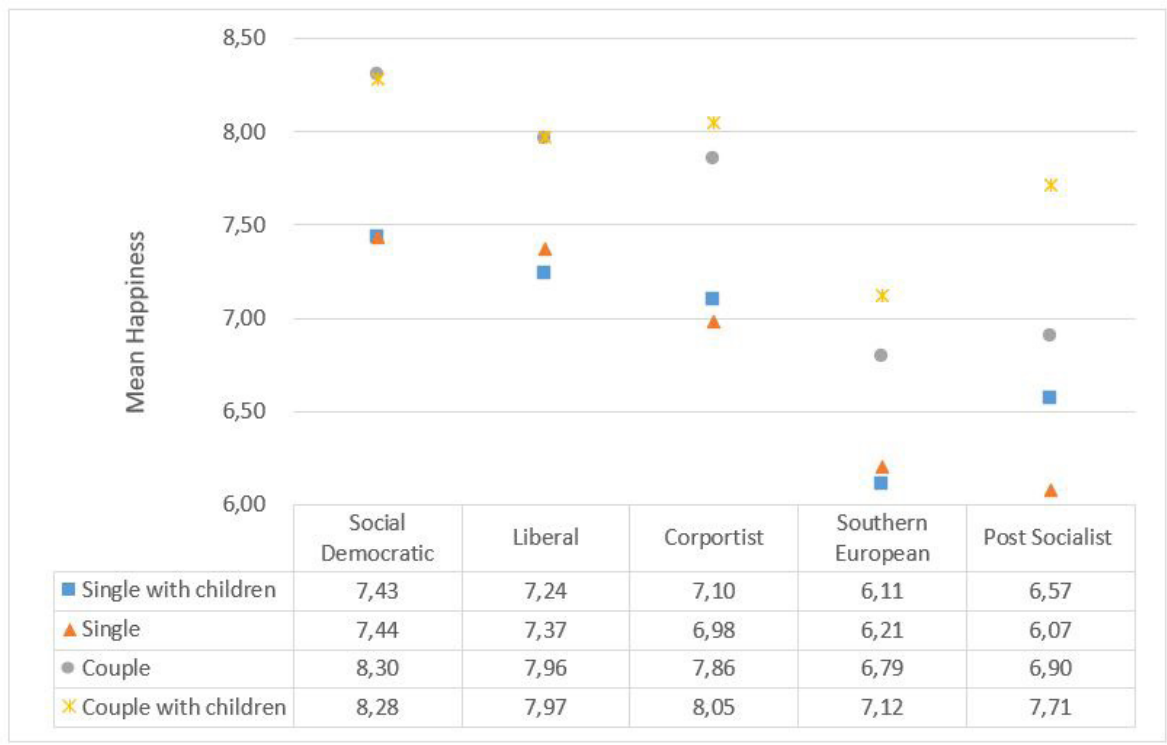

Source: European Quality of Life Survey 2016

Graph 5 shows the mean happiness levels of individuals within the category of marital status in welfare states. Married couples with children were generally found to be the happiest group in most welfare states. In contrast, single parents and singles were the least happy groups. One-way ANOVA revealed that the difference between happiness levels of different household structures was significant for every welfare state regime. Post hoc analysis showed that the difference in happiness levels between the happiest group, couples with children, and the least happy group, singles with children, was the lowest in liberal countries (happiness mean difference $=0.73, \mathrm{p}<0.00$ ). It was the highest in postsocialist countries where singles were the least happy and married people with children were the happiest (happiness mean difference $=1.63, \mathrm{p}<0.00$ ). 


\section{Graph 6. Age groups and happiness}

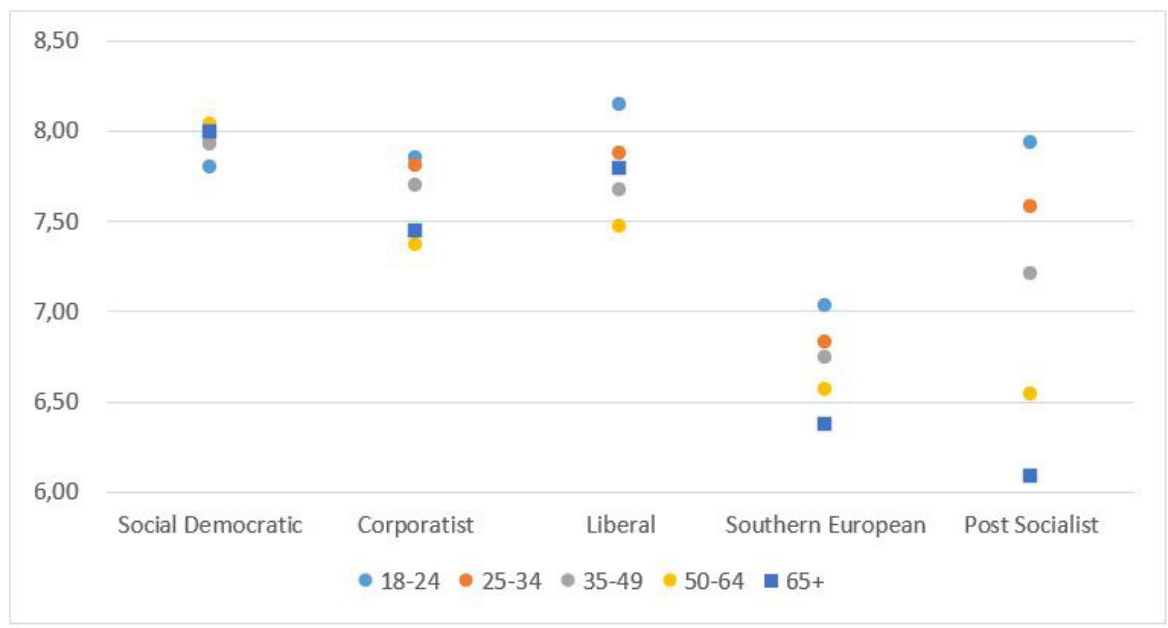

Source: European Quality of Life Survey, 2016

Graph 6 shows the mean happiness of diverse age groups in welfare states. One way ANOVA revealed that a person's age did not significantly affect happiness levels in social democratic welfare states $(F(4,4120)=1.46, p=$ .21). However, in all other welfare states, the difference in happiness levels between different age groups was significant. It was highest for young people aged between 18 and 25 in all welfare states except the social democratic welfare states. It gradually decreased with age. In corporatist and liberal welfare states people aged between 50 and 64 had the lowest happiness level. In southern European and post-socialist welfare states people aged over 65 had the lowest happiness level. Inequality was the highest in post-socialist countries where the elderly over 65 years of age were the least happy and young people aged between 18 and 24 were the happiest (happiness mean difference $=1.85 ; F(4$, $11071)=226.576, p<.00)$. 


\section{Graph 7. Education and happiness}

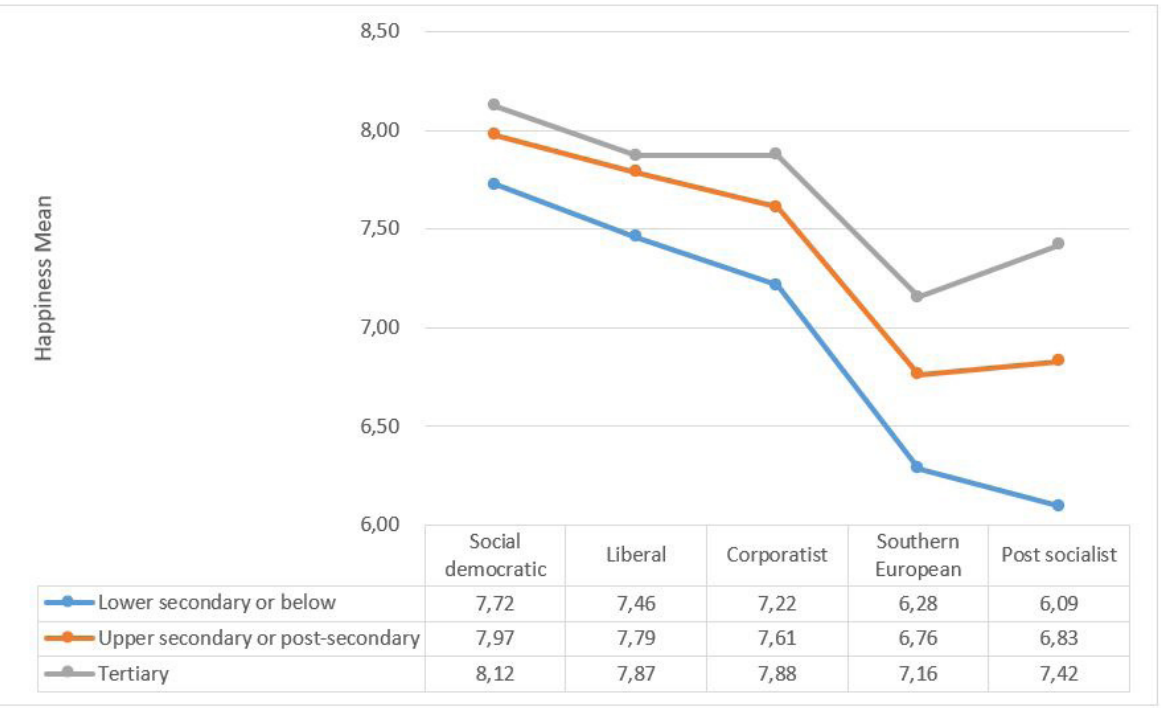

Source: European Quality of Life Survey, 2016

Graph 7 shows the mean happiness level of individuals in three education categories. People with higher education levels reported higher levels of happiness in all welfare states. One-way ANOVA revealed that the differences were significant for every welfare state. Happiness inequality between different education groups was lowest in social democratic countries (happiness mean difference between lowest and highest $=0.40 ; F(2,4098)=22.105, p<.00)$ whereas it was highest in post-socialist countries (happiness mean difference between lowest and highest $=1.32 ; F(2,11025)=258.664, p<.00)$. Post hoc analysis revealed that the difference between tertiary and upper or post-secondary in the liberal group was insignificant (happiness mean difference $=.08, \mathrm{p}=.60$ ).

\section{Discussion}

In the present study, the inequality of happiness levels across different welfare states was investigated. Welfare state clusters developed by EspingAndersen(1999) were mainly used in cross regime comparisons, with the addition of the post-socialist welfare regime. Welfare regimes influence the shape of inequalities differently across nations. Several studies demonstrated that of the four regime types identified by Esping-Andersen, the social democratic welfare regime is the model with the highest equalizing effects 
(Scruggs \& Allan, 2008; Sachweh \& Olafsdottir, 2012). In line with these findings, the present study found that social democratic welfare states had the lowest happiness inequalities. Both overall happiness inequality and the happiness inequality between different socio-demographic groups were generally the lowest in these countries. Publicly sponsored and administered programs with widespread and universal coverage and comparatively egalitarian benefits characterize social democratic welfare states (Swank, 2000). As a result, this system promotes an egalitarian society as measured by different indicators such as income, health, and happiness.

Gandelman and Porzecanski (2013) found that happiness inequality in high income countries was lower than in lower income countries. In line with this finding, the present study found that post-socialist and southern European welfare states that have lower incomes compared to others, had the highest happiness inequalities respectively. After the collapse of communist regimes, post-socialist countries have been experiencing ongoing social and economic transformations that have deepened inequalities. In these countries, public social welfare provision is still incomplete and inadequate (Polese, Morris, \& Kovacs, 2015). Similarly, in southern European countries, shrinking funds for public services especially after the 2008 economic crisis have exacerbated already-existing inequities, limiting access, and risking the quality of public services (Serapioni \& Matos, 2014).

Liberal welfare states are characterized by a dependence on the market for welfare services. Means-tested assistance, modest universal transfers, or modest social insurance plans predominate in these countries (Esping-Andersen, 1990). As a result, post-government income inequality is significantly higher in liberal welfare states compared to social democratic and conservative ones (Goodin et al., 1999). On the other hand, corporatist regimes are characterized by a high level of public support and a strong social insurance system (Sachweh \& Olafsdottir, 2012). It might be expected that dependence on the market in liberal states would create high happiness inequalities given that it creates a sense of insecurity. However, in this study, it was found that overall happiness inequality had similar levels for corporatist and liberal welfare states. Inequalities were not as high in these countries as in the southern European and post-socialist welfare states but they were higher compared to the social democratic welfare states. High living standards and well-functioning market systems seem to 
tolerate the possible negative consequences of market dependence, at least for the liberal countries in this study.

It was found that there was a slight increase in happiness inequality from 2003 to 2016. This increase might be due to the 2008 economic crisis, which was the most severe crisis post-war Europe had ever faced. The 2008 economic crisis resulted in increased social inequality and poverty, as well as increased job insecurity, rising unemployment, and privatization of public goods and services, all of which harm people's and societies' well-being. For example, in Iceland, the percentage of people in financial difficulty increased from 14.3\% in 2007 to 20.4 percent in 2009 (Gudmundsdottir, 2013). In the European Union, the unemployment rate, which is one of the strongest indicators of happiness, jumped from roughly 6\% in 2008 to 11\% in 2014 (Yong, 2019). The poor, old, and young, who were not well equipped to deal with the effects of rising prices, shrinking incomes, job losses, and decreases in critical public services such as social welfare, health care, and education, were particularly severely struck by the economic crisis (Ötker-Robe \& Podpiera, 2013).

According to empirical studies income inequality is negatively associated with happiness (Asadullah \& Chaudhury, 2012; Gandelman \& Porzecanski, 2013). This is explained by a psychological phenomenon known as the jealousy effect, which states that when income inequality is great, people feel dissatisfied because they are envious of their wealthier counterparts (Senik, 2008). In line with this explanation, in this study it was found that in social democratic and corporatist welfare states, where the income gap is lower compared to other European countries, the happiness gap was also lower. However, in liberal welfare states that have higher income inequalities compared to other developed economies the happiness difference between the lowest and highest income quartiles was not as high as might be expected. Spiegel (2008) makes a distinction between the standard of living inequality and income inequality and demonstrates that within certain ranges of income inequality reduction in income share does not always accompany a reduction in the standard of living. This might explain why the happiness penalty was found to be lower in European liberal welfare states with high living standards.

Unemployment is a factor that can lower happiness levels to a great extent. The effect of unemployment on well-being has been revealed in many studies over the years. For example, Stuckler et al. (2009) found that every 1\% increase 
in unemployment corresponded to a $0.79 \%$ rise in suicides. In practically every country, unemployed people are substantially less happy than employed people (Gudmundsdottir, 2013; Aysan \& Aysan, 2017). Similar to these studies, in the present study, it was revealed that the happiness of the employed was significantly higher than that of the unemployed in every welfare state. However, it was also found that unemployment affected happiness differently in welfare states. For example, as might be expected, inequality was low in social democratic, and high in post-socialist welfare states. However, unlike other inequality areas, inequality was high in corporatist welfare states and low in southern-European states. One possible explanation might be that social norms play a role in the personal consequences of unemployment. Unemployment has a lower impact on happiness in places where it is more common and thus socially accepted (Layard, 2005) such as southern European societies with a particularly high youth unemployment rate. On the other hand, happiness in historically Protestant corporatist welfare states was influenced more by being unemployed than is the case in that of other welfare states because Protestants attach a lot of importance to work (Van Hoorn \& Maseland, 2013). Furthermore, the corporatist system offers few benefits for those outside the insurance model and tends to penalize individuals in precarious job situations.

Although the number of married couples with children has decreased and the normative dominance of marriage in Western societies has declined, there is extensive literature on the positive effects of marriage on well-being (Stack $\&$ Eshleman, 1998). Social support and social integration are two mechanisms emphasized for explaining the benefits of marriage (Vanassche, Swicegood, \& Matthijs, 2013). Although various psychological and physical costs accompany parenthood, people still choose to get married and have children, and a combination of both makes people happy (Kohler, Behrman, \& Skytthe, 2005). Supporting this literature, it was found that in all welfare states married couples either with or without children were the happiest groups. In contrast, happiness was found to be generally lowest for single parents who cannot share the burdens of parenthood. The happiness difference between the happiest group, couples with children, and the least happy group, singles with children, was the lowest in liberal countries. In societies where alternative family types are more common, happiness inequality might be lower. 
Generally, happiness and health go hand in hand. Happiness affects health just as health affects happiness. Physical and mental health affect happiness more than either income or employment status (Clark et al., 2019; Kushlev et al., 2020). Supporting the literature, the present study revealed that the happiness inequality of people with different health conditions was more significant compared to the inequalities in other socioeconomic categories. Even in the most egalitarian social democratic welfare states, health was a significant determinant of happiness. As might be expected, happiness inequality was found to be higher in southern European and post-socialist countries where health expenditures and quality of services are lower.

The relationship of age with happiness is ambiguous. Some claim that happiness and age has a negative correlation after a certain age (Chen, 2001; Edwards \& Klemmack, 1973), while others argue that happiness, starting from a high point in youth, declines until a certain midlife minimum then increases again in later years, creating a U-shaped relationship (Dolan et al., 2008; Kolosnitsyna, Khorkina, \& Dorzhiev, 2014). In the present study, the effect of age on happiness was found to be insignificant for social democratic countries. By contrast, the elderly were disadvantaged compared to younger individuals in southern European and post-socialist countries. This may be due to the low scope and quality of social services for the elderly, combined with comparatively low living standards in these countries.

Even though empirical evidence on the influence of education on happiness is inconclusive, certain empirical research shows that it has a considerable beneficial effect on happiness (Di Tella, MacCulloch, \& Oswald, 2003). Education boosts happiness by two basic mechanisms. The first direct channel evaluates the positive effects of knowledge acquisition on pleasure, self-esteem, and self-confidence. Education may also improve happiness indirectly by increasing the likelihood of finding a job, the quality of the job, higher compensation, and better health. (Cunado \& Perez de Garcia, 2012). In this study, it was found that people with higher education levels reported higher levels of happiness in all welfare states. However, the happiness inequality between different education groups was lowest in social democratic countries whereas it was highest in post-socialist countries. People with high education levels have higher income levels and a higher probability of being employed. In countries with low-income inequality and low unemployment level, the cost 
of being less educated might be lower, thus leading to lower happiness inequalities, as in the case of social democratic countries.

\section{Conclusion}

Numerous studies have been carried out on the subject of happiness during the last few decades. Happiness is increasingly seen as a valid indicator of social progress and a public policy goal. Despite its increasing relevance in policy debates, research on happiness disparities across and within states, as well as how it might influence policy, is still not adequate. Extant literature on the effects of the welfare state on happiness is also inconclusive. Supporters of the welfare state claim that welfare states decrease inequalities and promote well-being by reducing market dependence through strong social protection systems.

Using the European Quality of Life Survey (EQLS) data set, this study revealed that social democratic welfare states had the lowest overall happiness inequalities. Happiness inequalities among different sociodemographic population groups were also low in these welfare states. Contrary to expectations, both overall inequality and inequality between different socio-demographic groups were not very high in liberal welfare states. Post-socialist and southern European welfare states had the highest happiness inequalities. Corporatist countries where inequalities were not generally high stood out with high inequality between employed and unemployed groups.

This study has some limitations. The country clusters approach does not allow us to see the variation within groups in the same country. The postsocialist group in particular, which consists of a large number of countries, deserves further analysis. Furthermore, single-item happiness measures are not enough to get a clearer picture of well-being. Other life evaluations (such as satisfaction with family, income) are also important aspects of well-being. More research is needed to gain a deeper and more nuanced understanding of happiness and happiness inequality. 


\section{References}

Ahlquist, J. S., \& Breunig, C. (2011). Country clustering in comparative political economy. MPIfG Discussion Paper 09/5. Cologne.

Asadullah, M. N., \& Chaudhury, N. (2012). Subjective well-being and relative poverty in rural Bangladesh. J. Econ. Psychol., 33, 940-950.

Aysan, M. F. (2018). Between Risks and Opportunities: Social Policies in Contemporary Turkey. In B. M. Aysan A., Turkish Economy (pp. 101-120). Palgrave Macmillan, Cham.

Aysan, M. F. (2020). Geleceğin Türkiyesinde Sosyal Politikalar. İstanbul: İlke Yayınları.

Aysan, M. F., \& Aysan, U. (2017). The effect of employment status on life satisfaction in Europe. In D. H. Bilgin M., Empirical Studies on Economics of Innovation, Public Economics and Management. Eurasian Studies in Business and Economics (Vol. 6, pp. 335-347). Springer, Cham.

Becchetti, L., Massari, R., \& Naticcioni, P. (2013). The drivers of happiness inequality: suggestions for promoting social cohesion. Oxford Economic Papers, 66(2), 419-442.

Bjørnskov, C., Dreher, A., \& Fischer, J. A. (2007). The bigger the better? Evidence of the effect of government size on life satisfaction around the world. Public Choice, 1303(4), 267-292.

Blanchflower, D., \& Oswald, A. (2000). Well-being Over Time in Britain and the USA. Working Paper 7487. Cambridge, MA: National Bureau for Economic Research,

Bob, D. (2000). Eastern European welfare states: the impact of the politics of globalization. Journal of European Social Policy, 10(2), 146-161.

Bok, D. (2010). The politics of happiness: What government can learn from the new research on well-being. Princeton NJ: Princeton University Press.

Brady, D. (2009). Rich Democracies, Poor People: How Politics Explain Poverty. Oxford: Oxford University Press.

Chen, C. (2001). Aging and life satisfaction. Social Indicators Research, 54(1), 57-79.

Clark, A., Flèche, S., \& Senik, C. (2012). The great happiness moderation. . SOEP paper No. 468 .

Clark, A. E., Flèche, S., Layard, R., Powdthavee, N., \& Ward, G. (2019). Health of Mind and Body. The Origins of Happiness, 89-104.

Clark, A., Fleche, S., \& Senik, C. (2016). Economic Growth Evens Out Happiness: Evidence from Six Surveys. The Review of Income and Wealth, 62(3), 405-602.

Cunado, J., \& Perez de Garcia, F. (2012). Does Education Affect Happiness? Evidence for Spain. Social Indicators Research, 108, 185-196.

Delle Fave, A., Brdar, I., Freire, T., Vella-Brodrick, D., \& Wissing, M. P. (2011). The Eudaimonic and Hedonic Components of Happiness: Qualitative and Quantitative Findings. Social Indicators Research, 100(2), 185-207.

Di Tella, R., MacCulloch, R. J., \& Oswald, A. J. (2003). The macroeconomics of happiness. Review of Economics and Statistics, 85(4), 809-827. 
Diener, E. (2009). Subjective Well-Being. In E. Diener, The Science of Well-Being: The Collected Works of Ed Diener; Social Indicators Research Series (Vol. 37, pp. 11-58). Springer Science \& Business Media.

Diener, E. D., Emmons, R. A., Larsen, R. J., \& Griffin, S. (1985). The satisfaction with life scale. Journal of personality assessment. 49(1), 71-75.

Dolan, P., Peasgood, T., \& White, M. (2008). Do we really know what makes us happy? A review of the economic literature on the factors associated with subjective well-being. Journal of Economic Psychology, 29(1), 94-122.

Edwards, J. N., \& Klemmack, D. L. (1973). Correlates of Life Satisfaction: A Reexamination1. Journal of Gerontology, 28(4), 497-502.

Esping-Andersen, G. (1990). Three Worlds of Welfare Capitalism. Cambridge: Polity Press.

Esping-Andersen, G. (1999). Social Foundations of Post-Industrial Economies, Oxford: Oxford University Press.

Esping-Andersen, G., \& Myles, J. (2012). Economic Inequality and the Welfare State. In The Oxford Handbook of Economic Inequality.

Eurofound. (2013). Quality of life in Europe: Subjective Well-being. Luxembourg: Publications Office of the European Union.

Eurofound. (2014). Developing a country typology for analysing quality of life in Europe. Luxembourg: Publications Office of the European Union.

Ferrera, M. (1996). The "Southern" model of welfare in social Europe. Journal of European Social Policy, 6(1), 17-37.

Fraser, N., \& Gordon, L. (1994). A genealogy of dependency: Tracing a keyword of the U. S. welfare state. Signs, 19(2), 307-336.

Frey, B. S., \& Stutzer, A. (2010). Happiness and economics: How the economy and institutions affect human well-being. Princeton University Press.

Gandelman, N., \& Porzecanski, R. (2013). Happiness Inequality: How Much is Reasonable? Social Indicators Research, 110(1), 257-269.

Gainer, M. (2013). Assessing Happiness Inequality in the Welfare State: Self-Reported Happiness and the Rawlsian Difference Principle. Social Indicators Research(114), 453-464.

Goff, L., Helliwell, J. F., \& Mayraz, G. (2016). The Welfare Costs of Well-Being Inequality. NBER Working Paper Series. Cambridge: Nationa Bureau of Economic Research.

Goodin, R. E., Headey, B., Muffels, R., \& Dirven, H.-J. (1999). The Real Worlds of Welfare Capitalism. In The Real Worlds of Welfare Capitalism.

Gudmundsdottir, D. G. (2013). The Impact of Economic Crisis on Happiness. Social Indicators Research, 110(3), 1083-1101.

Gurr, T. (1994). Peoples against states: ethnopolitical conflict and the changing world system. International Studies Quarterly, 38, 347-377. 
Helliwell, J., Layard, F. R., \& Sachs, J. D. (2016). World Happiness Report.

Helliwell, J., Layard, F. R., \& Sachs, J. D. (2018). World Happiness Report.

Inglehart, R. (2009). Democracy and happiness: what causes what? . In A. K. Dutt, \& B. Radcliff, Happiness, Economics and Politics: Towards a Multi-disciplinary Approach (pp. 256-270). UK,USA: Edward Elgar Publishing Limited.

Keyes, C. L., \& Ed Haidt, J. (2003). Flourishing: Positive psychology and the life welllived. Washington, DC, US: American Psychological Association.

Kohler, H.-P., Behrman, J. R., \& Skytthe, A. (2005). Partner ? children = happiness? The effects of partnerships and fertility on well-being. Population and Development Review, 31, 407-445.

Kolosnitsyna, M., Khorkina, N., \& Dorzhiev, K. (2014). What happens to happiness when people get older? Socio-economic determinants of life satisfaction in later life. Working Paper. National Research University Higher School of Economics.

Kotakorpi, K., \& Laamanen, J.-P. (2010). "Welfare state and life satisfaction: Evidence from public health care." 77.307. Economica, 77(307), 565-583.

Kushlev, K., Heintzelman, S. J., Lutes, L. D., Wirtz, D., Kanippayoor, J. M., Leitner, D., \& Diener, E. (2020). Does Happiness Improve Health? Evidence From a Randomized Controlled Trial. Psychological Science, 31(7), 807-821.

Layard, R. (2005). Happiness: Lessons from a new science. London: Penguin.

Lemieux, P. (2013). American and European Welfare States: Similar Causes, Similar Effects,. Cato Journal, 33(2), 227-232.

Lyubomirsky, S., \& Lepper, H. S. (1999). A measure of subjective happiness: Preliminary reliability and construct validation. Social Indicators Research, 46, 137-155.

Mahler, V., \& Jesuit, D. (2006). Fiscal redistribution in the developed countries. SocioEconomic Review, 4, 483-512.

Oishi, S. S. (2011). Income inequality and happiness. Psychological science, 22(9), 1095-1100.

Okulicz-Kozaryn, A. (2015, AUTUMN). Inequality Hurts Happiness. Warsaw Forum of Economic Sociology 6:2(12) Autumn 2015, 6(2).

Ono, H., \& Schultz Lee, K. (2013). Welfare States and the Redistribution of Happiness. Social Forces, 92(2), 789-814.

Ötker-Robe, I., \& Podpiera, A. M. (2013). The social impact of financial crises: evidence from the global financial crisis. World bank.

Ott, J. (2005). Level and equality of happiness in nations: Does happiness of a greater number imply greater inequality of happiness? Journal of Happiness Studies, Special Issue on Inequality of Happiness in Nations(6), 397-420.

Ovaska, T., \& Takashima, R. (2010). Does a Rising Tide Lift All the Boats? Explaining the National Inequality of Happiness. Journal of Economic Issues, 44(1), 205-224.

Pacek, A., \& Radcliff, B. (2008). Assessing the Welfare State: The Politics of Happiness. Perspectives on Politics, 6(2), 267-277. 
Polese, A., Morris, J., \& Kovacs, B. (2015). Introduction: The Failure and Future of the Welfare State in Post-socialism. Journal of Eurasian Studies, 6(1), 1-5.

Quick, A. (2015). Inequalities in wellbeing Challenges and opportunities for research and policy. The New Economics Foundation.

Rothstein, B. (1998). Just Institutions Matter: The Moral and Political Logic of the Universal Welfare State. Cambridge: Cambridge University Press.

Ryan, R. M., \& Deci, E. L. (2001). On happiness and human potentials: a review of research on hedonic and eudaimonic well-being. Annual Review of Psychology(52), 141-166.

Ryff, C. D., Boylan, J. M., \& Kirsch, J. A. (2021). Eudaimonic and hedonic well-being: An integrative perspective with linkages to sociodemographic factors and health. Measuring Well-Being: Interdisciplinary Perspectives from the Social Sciences and the Humanities, 92-135.

Sachweh, P., \& Olafsdottir, S. (2012). The welfare state and equality? Stratification realities and aspirations in three welfare regimes. European Sociological Review, 28(2), 149-168.

Schröder, M. (2016). Welfare States and their Inequality as a Result of Cultural Differences. In A. Machin, \& N. (. Stehr, Understanding Inequality: Social Costs and Benefits (pp. 39-67). Wiesbaden: Springer VS.

Scruggs, L. A., \& Allan, J. P. (2008). Social Stratification and Welfare Regimes for the Twenty-First Century: Revisiting The Three Worlds of Welfare Capitalism. World Politics, 60(4), 642-664.

Senik, C. (2008). Ambition and jealousy: income interactions in the "Old" Europe versus the "New" Europe and the United States. Economica, 75, 495-513.

Serapioni, M., \& Matos, A. R. (2014). Citizen participation and discontent in three Southern European health systems. Social Science \& Medicine, 123, 226-233.

Spiegel, U. (2008). Income inequality vs . Standard of living inequality. The American Economist, 52(1), 49-57.

Stack, S., \& Eshleman, R. (1998). Marital Status and Happiness: A 17-Nation Study. Journal of Marriage and Family, 60(2), 527-536.

Stevenson, B., \& Wolfers, J. (2008). Economic Growth and Subjective Well-Being: Reassessing the Easterlin Paradox. Brookings Papers on Economic Activity, 39(1), $1-102$.

Stiglitz, J., Sen, A., \& Fitoussi, J. (2009). Report by the commission on the measurement of economic performance and social progress. Commission on the Measurement of Economic Performance and Social Progress, Paris.

Stuckler, D., Basu, S., Suhrcke, M., Coutts, A., \& McKee, M. (2009). The public health impact of of economic crisis and alternative policy responses in Europe. Lancet, 374(9686), 315-323. 
Swank, D. (2000). Social Democratic Welfare States in a Global Economy: Scandinavia in Comparative Perspective. In R. Geyer, C. Ingebritsen, \& J. Moses, Globalization, Europeanization and the end of Scandinavian social democracy? (pp. 85-138). London: Palgrave Macmillan.

The Happiness Research Institute. (2015). Happiness Equality Index Europe 2015.

Thelen, K. A. (2014). Varieties of Liberalization and the New Politics of Social Solidarity. Cambridge Studies in Comparative politics. Cambridge: Cambridge University Press.

Tullock, G. (1971). The paradox of revolution. Public Choice, 11, 89-100.

Van Hoorn, A., \& Maseland, R. (2013). Does a Protestant work ethic exist? Evidence from the well-being effect of unemployment. Journal of Economic Behavior \& Organization, 91, 1-12.

Vanassche, S., Swicegood, G., \& Matthijs, K. (2013). Marriage and children as a key to happiness? Cross-national differences in the effects of marital status and children on well-being. , 14(2), . Journal of Happiness Studies, 14(2), 501-524.

Veenhoven, R. (2000). Well-being in the welfare state: Level not higher, distribution not more equitable. Journal of Comparative Policy Analysis: Research and Practice, 2(1), 91-125.

Veenhoven, R. (2014). Livability theory. In A. C. Michalos, Encyclopedia of Quality of Life and Well-Being Research (pp. 3645-3647). Dordrecht: Springer.

Veenhoven, R., \& Ehrhardt, J. (1995). The Cross-National Pattern of Happiness: Test of Predictions Implied in Three Theories of Happiness. Social Indicators Research, 34(1), 33-68.

Veenhoven, R., \& Kalmijin, W. (2005). Inequality-adjusted happiness in nations: Egalitarianism and utilitarianism married in a new index of societal performance. Journal of Happiness Studies Special Issue on 'Inequality of Happiness in nations', 6, 421-445.

Watson, D., Clark, L. A., \& Tellegen, A. (1988). Development and validation of brief measures of positive and negative affect: the PANAS scales. Journal of personality and social psychology, 54(6), 1063.

Yong, E. (2019). Unemployment and the European Union, 2000-2017: structural exploration of distant past economic experience and future prosperity. Economic Structures, 8(30). 
